\title{
Clinical impact of wireless capsule endoscopy for small bowel investigation (Review)
}

\author{
ALIN GABRIEL IONESCU ${ }^{*}$, ADINA DORINA GLODEANU ${ }^{2}$, MIHAELA IONESCU $^{3 *}$, \\ SORIN IOAN ZAHARIE ${ }^{4}$, ANA MARIA CIUREA ${ }^{5 *}$, ANDREEA LOREDANA GOLLI $^{6}$, \\ NIKOLAOS MAVRITSAKIS ${ }^{7}$, DIDI LILIANA POPA ${ }^{8}$ and CRISTIN CONSTANTIN VERE ${ }^{9}$ \\ Departments of ${ }^{1}$ Medical History, ${ }^{2}$ Internal Medicine, ${ }^{3}$ Medical Informatics and Biostatistics, ${ }^{4}$ Nephrology, \\ ${ }^{5}$ Oncology, ${ }^{6}$ Public Health Management, University of Medicine and Pharmacy of Craiova, 200349 Craiova; \\ ${ }^{7}$ Department of Physical Education and Sport, '1 Decembrie 1918' University, 510009 Alba Iulia; \\ ${ }^{8}$ Department of Information and Communication Technology, University of Craiova, 200585 Craiova; \\ ${ }^{9}$ Department of Gastroenterology, University of Medicine and Pharmacy of Craiova, 200349 Craiova, Romania
}

Received October 13, 2021; Accepted November 12, 2021

DOI: $10.3892 / \mathrm{etm} .2022 .11188$

\begin{abstract}
Wireless capsule endoscopy is currently considered the gold standard in the investigation of the small bowel. It is both practical for physicians and easily accepted by patients. Prior to its development, two types of imaging investigations of the small bowel were available: radiologic and endoscopic. The first category is less invasive and comfortable for patients; it presents the ensemble of the small bowel, but it may imply radiation exposure. Images are constructed based on signals emitted by various equipment and require special interpretation. Endoscopic techniques provide real-time colored images acquired by miniature cameras from inside the small bowel, require interpretation only from a medical point of view, may allow the possibility to perform biopsies, but the investigation only covers a part of the small bowel and are more difficult to accept by patients. Wireless capsule endoscopy is the current solution that overcomes a part of the previous drawbacks: it covers the entire small bowel, it provides real-time images acquired by cameras, it is painless for patients, and it represents an abundant source of information for physicians. Yet, it lacks motion control and the possibility to perform biopsies
\end{abstract}

Correspondence to: Dr Adina-Dorina Glodeanu, Department of Internal Medicine, University of Medicine and Pharmacy of Craiova, 2-4 Petru Rareş Street, 200349 Craiova, Romania

E-mail: glodeanuadina@yahoo.com

Dr Nikolaos Mavritsakis, Department of Physical Education and Sport, '1 Decembrie 1918' University, 5 Gabriel Bethlen Street, 510009 Alba Iulia, Romania

E-mail: geromed_ro@yahoo.com

*Contributed equally

Key words: endoscopy, wireless capsule endoscopy, small bowel investigation, medical devices, small intestine pathology or administer drugs. However, significant effort has been oriented in these directions by technical and medical teams, and more advanced capsules will surely be available in the following years.

\section{Contents}

1. Introduction

2. Brief history of small bowel investigation

3. A brilliant idea

4. Wireless capsule endoscopy (WCE)

5. WCE systems

6. Uses for WCE

7. The future of WCE

\section{Introduction}

For many years, the small bowel has been a hidden part of the human body, with no possibility to investigate it until 1895, when the first X-ray was invented (1). Only then, physicians had the chance to glimpse at this organ and to start imagining the possibilities that this discovery led to.

The first steps in medical imaging were faint and offered very few data with clinical meaning. But still, they represented the start of a process that was continuously improved with new devices, techniques, processing activities and modern ways to interpret the acquired images.

\section{Brief history of small bowel investigation}

The first imaging procedure used for the investigation of the small bowel was the X-ray. In classic abdominal X-rays, the small bowel is located centrally within the image, and the colon frames it peripherally. The mucosal folds are visible across the entire width of the small bowel, but still the image quality was quite poor, superimposition of various structures 
was and still is inevitable, thus the associated pathology was hard to identify and diagnose.

A significant contribution in the visibility of various characteristics of the small bowel in an X-ray was represented by a prior ingestion of a contrast agent, which emphasized the aspect of specific areas within the acquired images. Initially, bismuth preparations were used for these purposes, at the end of XIX $^{\text {th }}$ century, but in 1910, Krause, Bachem and Gunther from Bonn Polyclinic recommended barium sulfate as replacement since bismuth was considered too toxic (1). Barium has two very important properties: it is adherent to the small intestine wall (contour, shape, wall lining and size are more visible), and it absorbs X-rays, therefore the initial rays are strongly attenuated and the impression they leave on the receptor, for that specific area, is very close to white (corresponding to the imaging aspect when the ray is completely attenuated). The small bowel was more visible on the new X-rays, in almost white shades. Intestinal anses are easier to spot, and so are the eventual pathological lesions.

As the medical world progressed, so did the imaging investigation techniques. The usage of contrast agents was exploited even more; later on, double contrast small bowel investigation started to be used. The development of CT technology in 1989 led to a new direction regarding imaging investigations, so in the early 1990's CT enterography brought new perspectives on the small bowel.Other radiology techniques without radiation exposure were also used: magnetic resonance imaging, magnetic resonance enteroclysis and enterography, ultrasound or contrast enhanced ultrasound (2). These techniques are less invasive and better accepted by patients, but they lack the possibility to perform biopsies.

This drawback was solved by the endoscopic techniques: push enteroscopy, ileocolonoscopy, intraoperative enteroscopy, which are however invasive and not comfortable for patients; still, from an imaging point of view, they offer real time images of the small bowel, acquired with miniature cameras, not images reconstructed by various techniques, such as radiology investigations (3).

All these investigations have advantages and disadvantages and offer complementary data on the small bowel. But what was missing was an investigation that would allow a complete and accurate visualization of the small bowel.

\section{A brilliant idea}

The previous endoscopic techniques depended on a wire, a cable or a similar physical element that could not be extended enough to cover the entire small bowel's length. The next step was clear: either create a very long component, that would indeed be long enough to cover it all (this would have the disadvantage of being hard to manipulate) or create a very small device that would be swallowed by the patient and capture images from inside the gastrointestinal (GI) tract (a very difficult task at that time, with the available electronic components).

However, this theoretical concept found its inventor in 1981. Gavriel Iddan, an electrical engineer working for the army, together with his friend Eitan Scapa (gastroenterologist), laid the foundation of what would later become the wireless capsule endoscopy (WCE). It took him 10 years, a sabbatical leave, all of his experience in guided-missile technology and the recently emerged miniature charged coupled device (CCD) to come up with an initial solution: a small device with a video camera based on CCD (which would simply take pictures of the inside of the small bowel) and an electrical 'umbilical cord' that would provide the power supply $(4,5)$.

This device was not practical, due to the length needed for the electrical cord (which would have been impossible to achieve). Thus, a wireless solution had to be identified, in the form of a mini transmitter, powered by batteries, attached to the CCD camera. Every image would be transmitted outside the patient, being subsequently recorded. But the challenges were not over yet. The mini batteries would only provide about 10 min lifetime. In addition, the light generated by a normal bulb (based on a heated filament) was faint and required much energy. The solution came along with the technological progress, since the recently invented complementary metal oxide semiconductor (CMOS) would replace the former CCD (saving about $99 \%$ of the requested energy) and, at the same time, the new light-emitting diode (LED) technology would replace the previous light bulb. Even so, the problems were not over yet. The light was accurate, but the CMOS-based camera did not generate sharp images, as the body temperature decreased the signal to noise ratio, through the presence of random photons. Thus, Iddan's team had to invent a new CMOS imager that would improve the image quality, given the context of the acquisition process (4).

To date, the brilliant idea of Gavriel Iddan was pretty much materialized. His device had enough power to capture images, good light, and a proper acquisition device to obtain sharp images, completed by a transmitter to send the images outside. Now, only several hours were needed for the patient to remain in the doctor's office, and for the doctor to watch in real time the acquired images. Again, this generated a new challenge. This time, the solution was easier to identify: a recorder would be attached to the patient's abdomen and it would receive and store all images captured by the device inside. This complex equipment was completed by a software package that would process the images stored within the recorder, composing a film that would be later watched by the examining physician $(5,6)$.

In parallel, Paul Swain was independently studying the use of mini-cameras for the same purpose. He succeeded to send real time images from a pig's stomach during an endoscopy, to a video screen (7).

In 1997, Iddan and Swain decided to join forces and, two years later, the first working prototypes were being produced by Given Imaging R\&D. In 2000, Iddan and his team performed and reported the first successful studies on animals (8). Not long afterwards, the first studies performed on humans were also completed in 2001. In the same year, this new device received clearance from the US Food and Drug Administration (FDA), and thus Given Imaging produced the first wireless capsules for small bowel investigation, PillCam SB (9). This was just the beginning.

\section{Wireless capsule endoscopy (WCE)}

The device invented by Iddan is in fact a capsule very similar to a large pill. It is composed of a set of CMOSs, 
Table I. Types of capsules for small bowel investigation.

\begin{tabular}{|c|c|c|c|c|c|}
\hline Capsule & $\begin{array}{c}\text { PillCam }{ }^{\mathrm{TM}} \text { SB } 3 \\
\text { Given Imaging }\end{array}$ & $\begin{array}{c}\text { EndoCapsule } \\
\text { Olympus America }\end{array}$ & $\begin{array}{l}\text { MiroCam }^{\circledR} \\
\text { Intromedic }\end{array}$ & $\begin{array}{l}\text { OMOM } \\
\text { Jianshan }\end{array}$ & $\begin{array}{c}\text { CapsoCam } \\
\text { CapsoVision }\end{array}$ \\
\hline Size (length/diameter) (mm) & $26.2 / 11.4$ & $26 / 11$ & $24.5 / 10.8$ & $27.9 / 13$ & $31 / 11$ \\
\hline Weight $(g)$ & 3.00 & 3.50 & $3.25-4.70$ & 6.00 & 4.00 \\
\hline Battery life & $8 \mathrm{~h}$ or longer & $8 \mathrm{~h}$ or longer & $11 \mathrm{~h}$ or longer & $6-8 \mathrm{~h}$ or longer & $15 \mathrm{~h}$ \\
\hline Resolution & $340 \times 340$ & $512 \times 512$ & $320 \times 320$ & $640 \times 480$ & $1,152 \times 212$ \\
\hline Frames per sec (fps) & $2 \mathrm{fps}$ or $2-6 \mathrm{fps}$ & $2 \mathrm{fps}$ & $3 \mathrm{fps}$ & $2 \mathrm{fps}$ & $20 \mathrm{fps}$ \\
\hline Field of view (degrees) & $156^{\circ}$ & $145^{\circ}$ & $170^{\circ}$ & $140^{\circ}$ & $360^{\circ}$ \\
\hline Communication & RFC & RFC & $\begin{array}{l}\text { Human body } \\
\text { communication }\end{array}$ & RFC & $\begin{array}{l}\text { Onboard } \\
\text { storage }\end{array}$ \\
\hline
\end{tabular}

RFC, radiofrequency communication.

lens, LEDs, batteries, a transmitter, and an antenna, all controlled by a microprocessor (10) and are included in an oval casing. The recorder is usually attached to the patient's abdomen.

The complete WCE procedure starts with patient fasting and the administration of medication needed to empty the small bowel and colon. Once this step is achieved, the patient receives the recorder that will be attached to his/her abdomen. The procedure continues with the capsule's activation. Once it is activated, it starts acquiring images, at a certain rate (expressed in number of frames/second). The patient swallows the capsule, which later advances through the digestive tract with the help of normal peristaltic movements.

Images are continuously transmitted in real time for as long as the device is active, and they are stored on the attached recorder (during the battery lifespan). When the batteries are no longer powering the device, no more images are recorded, and the capsule continues its movement within the patient's digestive tract until it is eliminated naturally.

Later, the images are downloaded to a computer, for a subsequent offline analysis. The physician watches the entire set of images and decides whether the patient has certain lesions or not.

\section{WCE systems}

In the following years, other companies also started producing new wireless capsules for the digestive tract investigation. There are 5 types of capsules for the small bowel, each of them being briefly presented in Table I (11).

In 2004 and 2006, Given Imaging extended the concept initiated with the first capsule prototype, by creating dedicated capsules for the esophagus and colon (PillCam ESO and PillCam COLON). These new capsules were improved by having CCDs at both ends and thus they can record images from both directions (12). This innovative step increases the chances to detect any potential lesion, by presenting two different perspectives upon every area of the investigated GI segment.
In 2006, the same company produced a new device: AGILE Patency capsule, for patients with known or suspected strictures who presented with a major risk regarding a potential blockage of the capsule within their GI tract. In this case, surgery would represent the only solution to remove the capsule. The patency capsule is made of lactose and barium. In case it remains stuck at a certain location of the GI tract, the lactose casing dissolves within 30 to $100 \mathrm{~h}$ from ingestion. The contrast agent (barium) is then released, and it may be detected by X-ray or CT, thus the stricture location is well identified (13). In case the patency capsule is eliminated intact, there is no risk for the patient to ingest the investigation capsule.

\section{Uses for WCE}

Initially, WCE was considered as complementary to the existing endoscopic and radiological techniques for the GI tract investigation. Since 2003, it became the main method for exploring the small bowel, due to its large number of images acquired during its functioning time, and implicitly the abundant amount of information offered and also due to its accuracy in the identification of the suspected pathology $(14,15)$.

According to current guidelines, WCE is recommended as a diagnosis imaging tool, both for adults and children above 2 years of age, in the following circumstances: i) to investigate obscure gastrointestinal bleeding, if there is a suspicion that the source is the small bowel, only after upper and lower endoscopy have excluded a potential bleeding source in the superior segment of the digestive tract or colon; ii) to perform an initial evaluation of patients for whom there is a suspicion of Crohn's disease, when small bowel follow-through (SBFT) or enteroclysis, including CT enteroclysis and upper and lower endoscopy are non-diagnostic AND there is no suspected or confirmed gastrointestinal obstruction, stricture, or fistulae; iii) to perform a re-evaluation of patients with Crohn's disease, when they still present symptoms even if the correct treatment has been administered, and patients do not present strictures, obstructions or fistulae; iv) for suspected small intestinal tumors; v) for patients older than 35 years of age diagnosed with polyposis syndrome or with Lynch syndrome; vi) for refractory undiagnosed malabsorptive 
Table II. WCE performance compared to other techniques in the detection of obscure gastrointestinal bleeding.

\begin{tabular}{|c|c|c|c|c|c|c|c|}
\hline \multirow[b]{2}{*}{ Authors, year } & \multicolumn{7}{|c|}{ Obscure gastrointestinal bleeding } \\
\hline & $\begin{array}{c}\text { WCE } \\
(\%)\end{array}$ & $\begin{array}{c}\text { Push } \\
\text { enteroscopy (\%) }\end{array}$ & Enteroclysis (\%) & $\begin{array}{c}\text { MR } \\
\text { enteroclysis }(\%)\end{array}$ & $\begin{array}{c}\mathrm{CT} \\
\text { enteroclysis }(\%)\end{array}$ & $\begin{array}{c}\text { Angiography } \\
(\%)\end{array}$ & (Refs.) \\
\hline Segarajasingam et al, 2015 & 73 & 49 & - & - & - & - & (22) \\
\hline Triester et al, 2005 & 63 & 28 & - & - & - & - & $(23)$ \\
\hline Ell et al, 2002 & 66 & 15 & - & - & - & - & (24) \\
\hline Lewis and Swain, 2002 & 55 & 33 & - & - & - & - & $(25)$ \\
\hline Mylonaki et al, 2003 & 68 & 32 & - & - & - & - & (26) \\
\hline Triester et al, 2005 & 67 & - & 8 & - & - & - & $(23)$ \\
\hline Laine et al, 2010 & 30 & - & 7 & - & - & - & $(27)$ \\
\hline Van Weyenberg et al, 2013 & 38 & - & - & 40 & - & - & $(28)$ \\
\hline Khalife et al, 2011 & 53 & - & - & - & 34 & - & $(29)$ \\
\hline Leung et al, 2012 & 53 & - & - & - & - & 20 & $(30)$ \\
\hline
\end{tabular}

WCE, wireless capsule endoscopy; MR, magnetic resonance; CT, computed tomography.

syndromes with prior history of negative small bowel biopsy (for example, suspected celiac disease with prior negative biopsy); vii) to investigate anemia with concomitant iron deficiency, suspected to be of small bowel origin, after appropriate evaluation (at a minimum upper and lower endoscopy) has excluded a source of anemia from the upper GI tract and colon (16).

Before becoming the gold standard in the investigation of the small bowel, WCE has been extensively studied in comparison with other traditional evaluation methods, to ascertain which correctly identifies the present pathology and thus offers the best results. The use of the WCE procedure eliminates the risk of contracting an infection with multidrug-resistant germs, given the fact that Romania is one of the South-Eastern European countries with one of the highest prevalence rates of multidrug-resistant pathogens (17). Elderly patients are more susceptible to infection and complications due to the constant decline in physical function and compromised immune system (18); thus, WCE is more indicated for the diagnosis of digestive disorders in this category of patients. In patients with extra-respiratory tuberculosis, intra-abdominal and mediastinal lymphadenopathy also implies a diagnostic and management challenge in highly endemic regions for tuberculosis (19). In addition, WCE for the diagnosis of digestive disorders is an adequate alternative in patients with severe heart failure, for at least two reasons. The first is that the use of WCE eliminates the risk of deep sedation used in the classic endoscopic procedure (hypotensive episodes and even cardiorespiratory arrest may occur, through severe vagal reaction in response to pain). The second consideration is related to the elimination of the risk of aggravation of renal dysfunction (64\% present in patients with heart failure of classes III-IV NYHA) when classical digestive endoscopy is contraindicated and opt for CT examination with contrast substance (20). In patients with an abdominal aortic aneurysm, classical colonoscopy is a contraindication, and the use of WCE is an effective method of diagnosis for these patients as well (21). Tables II-V indicate a series of comparisons, by group of diseases. For most of these, WCE correctly diagnosed more patients, compared to other investigations (22-55).

\section{The future of WCE}

WCE presents numerous advantages. It is painless, comfortable, and non-invasive for the patient, and it is rich in information for the examining physician. In terms of diagnosis, the past decades have represented an extensive research period dedicated to automatic lesion detection, computer-aided diagnosis, removal of artifacts and non-informative frames, and reduction in the time spent for analysis (56-62). There are currently multiple software applications that perform automatic analysis and segmentation of all images acquired through this investigation, detect potential lesions, emphasize the areas with important content, and compute various parameters. Their main role is to help the examining physician in the overall analysis of each WCE result.

It does have disadvantages which include the lack of motion control, impossibility to implement biopsies, or to administrate local treatments. For each point, researches have tried to overcome these drawbacks and produce feasible solutions that will improve even more the accuracy of this procedure, and also to enrich it with more facilities, other than being just a diagnostic tool.

Motion control. There are several research directions for assuring the motion control of the capsule, mainly magnetic fields, small physical legs, or small fins. RF System Lab has worked on the Sayaka capsule which could have motion control using an external and an internal constant magnetic field. The capsule itself was modified by including an electromagnet inside the oval casing. Investigation using this capsule would imply an eternal stationary electromagnetic field [something similar to magnetic resonance imaging (MRI), for example] or a belt that the patient would have to wear over the chest (63). 
Table III. WCE performance compared to other techniques in the detection of Crohn's disease.

\begin{tabular}{|c|c|c|c|c|c|c|c|}
\hline \multirow[b]{2}{*}{ Authors, year } & \multicolumn{7}{|c|}{ Crohn's disease } \\
\hline & $\begin{array}{l}\text { WCE } \\
(\%)\end{array}$ & $\begin{array}{c}\text { MR } \\
\text { enterography } \\
(\%)\end{array}$ & $\begin{array}{c}\text { Push } \\
\text { enteroscopy } \\
(\%)\end{array}$ & $\begin{array}{c}\text { Enteroclysis } \\
(\%)\end{array}$ & $\begin{array}{c}\mathrm{CT} \\
\text { enterography } \\
(\%)\end{array}$ & $\begin{array}{l}\text { Ileocolonoscopy } \\
(\%)\end{array}$ & (Refs.) \\
\hline Choi et al, 2017 & 86 & 100 & - & - & - & - & $(31)$ \\
\hline Albert et al, 2005 & 93 & 78 & - & - & - & - & (32) \\
\hline Crook et al, 2009 & 93 & 71 & - & - & - & - & $(33)$ \\
\hline Jensen et al, 2011 & 100 & 86 & - & - & - & - & $(34)$ \\
\hline Triester et al, 2006 & 46 & - & 8 & - & - & - & $(35)$ \\
\hline Choi et al, 2017 & 66 & - & - & 21 & - & - & $(31)$ \\
\hline Triester et al, 2006 & 63 & - & - & 23 & - & - & $(35)$ \\
\hline Dubcenco et al, 2005 & 82 & - & - & 9 & - & 50 & (36) \\
\hline Voderholzer et al, 2005 & 61 & - & - & 49 & - & - & (37) \\
\hline Choi et al, 2017 & 73 & - & - & - & 23 & - & $(31)$ \\
\hline Triester et al, 2006 & 69 & - & - & - & 30 & - & (35) \\
\hline Eliakim, 2004 & 77 & - & - & - & 20 & - & $(38)$ \\
\hline Hara et al, 2006 & 71 & - & - & - & 53 & - & (39) \\
\hline Solem et al, 2008 & 83 & - & - & - & 83 & - & $(40)$ \\
\hline Triester et al, 2006 & 61 & - & - & - & - & 46 & $(35)$ \\
\hline Bourreille et al, 2006 & 68 & - & - & - & - & 61 & (41) \\
\hline Pons Beltrán et al, 2007 & 55 & - & - & - & - & 25 & (42) \\
\hline Hara et al, 2006 & 71 & - & - & - & - & 65 & (39) \\
\hline Solem et al, 2008 & 83 & - & - & - & - & 74 & (40) \\
\hline Leighton et al, 2013 & 55 & - & - & - & - & 25 & (43) \\
\hline
\end{tabular}

WCE, wireless capsule endoscopy; MR, magnetic resonance; CT, computed tomography.

Table IV. WCE performance compared to other techniques in the detection of tumors, Lynch syndrome and familial adenomatous polyposis (FAP).

\begin{tabular}{|c|c|c|c|c|c|c|c|}
\hline \multirow[b]{2}{*}{ Authors, year } & \multicolumn{7}{|c|}{ Tumors, Lynch syndrome and familial adenomatous polyposis } \\
\hline & $\begin{array}{l}\text { WCE } \\
(\%)\end{array}$ & $\begin{array}{c}\text { MR } \\
\text { enterography } \\
(\%)\end{array}$ & $\begin{array}{c}\text { Enteroclysis } \\
(\%)\end{array}$ & $\begin{array}{c}\text { CT } \\
\text { enterography } \\
(\%)\end{array}$ & $\begin{array}{l}\text { DBE } \\
(\%)\end{array}$ & $\begin{array}{c}\text { Patients } \\
\text { included } \\
\text { in study lot }\end{array}$ & (Refs.) \\
\hline Akin and Ersoy, 2012 (Tumors) & 66 & 22 & - & - & - & 9 & $(44)$ \\
\hline Akin and Ersoy, 2012 (FAP) & 66 & 16 & - & - & - & 6 & $(44)$ \\
\hline Costamagna et al, 2002 & 45 & - & 20 & - & - & 20 & $(45)$ \\
\hline Bailey et al, 2006 & 62 & - & 35 & - & - & 26 & $(46)$ \\
\hline Mata et al, 2008 & 29 & - & 12 & - & - & 24 & (47) \\
\hline Singeap et al, 2016 & 5 & - & - & 1 & - & 102 & $(48)$ \\
\hline Saurin et al, 2005 & 9 & - & - & 3 & - & 35 & (49) \\
\hline Ross et al, 2008 & 3 & - & - & - & 10 & 183 & $(50)$ \\
\hline Caspari et al, 2004 & 5 & - & - & - & 2 & 156 & $(52)$ \\
\hline Haanstra et al, 2015 & 11 & - & - & - & 6 & 155 & $(51)$ \\
\hline
\end{tabular}

WCE, wireless capsule endoscopy; MR, magnetic resonance; CT, computed tomography; DBE, double balloon enteroscopy.

Another system is represented by Odocam which has been designed with 3 miniature legs, each one carrying a wheel. Its legs are extendable and retractable, thanks to a micro-motor and custom-made torsion springs. The wheels represent 
Table V. WCE performance compared to other techniques in the detection of Peutz-Jeghers syndrome.

\begin{tabular}{|c|c|c|c|c|c|c|}
\hline \multirow[b]{2}{*}{ Authors, year } & \multicolumn{6}{|c|}{ Peutz-Jeghers syndrome } \\
\hline & $\begin{array}{l}\text { WCE } \\
(\%)\end{array}$ & $\begin{array}{l}\text { MRE } \\
(\%)\end{array}$ & $\begin{array}{c}\text { Enteroclysis } \\
(\%)\end{array}$ & $\begin{array}{c}\text { CT enterography } \\
(\%)\end{array}$ & $\begin{array}{l}\text { Patients included } \\
\text { in study lot }\end{array}$ & (Refs.) \\
\hline Caspari et al, 2004 & 40 & 20 & - & - & 20 & $(52)$ \\
\hline Brown et al, 2006 & 21 & - & 5 & - & 19 & (53) \\
\hline Mata et al, 2008 & 29 & - & 12 & - & 24 & (47) \\
\hline Brown et al, 2006 & 21 & - & 5 & - & 19 & $(53)$ \\
\hline Thomson et al, 2007 & 11 & - & 4 & - & 28 & $(54)$ \\
\hline Gupta et al, 2006 & 42 & - & - & 58 & 19 & $(55)$ \\
\hline
\end{tabular}

WCE, wireless capsule endoscopy; CT, computed tomography; MRE, magnetic resonance enterography.

micro-odometers, by registering each rotation they perform. As the wheels turn, their rotations are converted into distance to measure the distance covered by the device from the point of duodenal entry to each area/point of interest (63).

Another idea is to equip the capsule with two separate sets of 4 miniature legs, driven by independent motors that would control threaded rods by means of separate gears. These would generate the movement of two sections of legs, placed along the capsule.

Other authors thought to use fins instead of legs. This would allow the capsule to 'swim' inside the small bowel instead of 'walk' along its wall. The capsule would be equipped with a motor placed at the end of the capsule, which would drive the tail, causing swinging movement. The frequency of movements and amplitude would be adjusted using the embedded microprocessor. Fin size would be about 10 x $45 \mathrm{~mm}$, leading to an average speed of $1 \mathrm{~cm} / \mathrm{sec}(64)$.

Other researchers have imagined a type of robot made of five capsules: 4 legs and the initial capsule (representing the capsule mother, allowing the reconfiguration and connection of all other individual parts). The patient would have to swallow the individual components, and the robot would assemble itself within the human body. The four legs would have multiple functions, including movement, monitoring or biopsy (63).

MicroCam is designed to be a self-stabilizing capsule, containing a gelatin cap, superabsorbent polymer granules and a polylactic acid (PLA) mesh. The gelatin cap dissolves in aqueous medium, at body temperature, and releases an expandable stabilizing component, the PLA mesh (63).

SupCam comes with an innovation in terms of shape; it is a spherical endoscopic capsule (about $2 \mathrm{~cm}$ in diameter) which can be safely, and accurately, guided along the colonic lumen from the outside, by means of an electromagnet (65).

Soon motion control will become a part of WCE technology, since there is much need for the capsule to be able to adjust its position. This would allow the capsule to stop near potential lesions and acquire better images that help the examining physician to establish a more accurate diagnosis.

Biopsy facility. Another major direction of research regards biopsy, which represents an important step in the development of new capsules. A team of researchers have imagined a capsule with a conical mirror placed in its main axis and an associated biopsy module. The site of biopsy would thus be directly visible to the camera. It is one of the biggest advantages of this solution (the possibility of simultaneous biopsy and visualization of the region of interest). This prototype would collect small samples of tissue (e.g. polyp) and would store them inside the capsule, using an open chamber with a cutting tool, and a strained spring. When the string is released, under the action of an external magnetic field, the cutting tool performs a rotation movement, collecting and storing the biopsy material within the open chamber (66).

Another team of researchers imagined a capsule with a special tank within its casing that would release a set of micro-grippers meant to collect small pieces of tissue (67). These micro-grippers are like a 6-point star made of shape memory metal. At temperatures below $36^{\circ} \mathrm{C}$, the points are connected, and the star is closed. Once they are released from the capsule inside the patient's digestive tract, where the temperature exceeds the threshold value, they open and then they close again in the opposite direction. During this process they are able to collect the biopsies from their current location. This capsule may also present a special tank with drugs to be released in a chosen location.

Drug administration. Targeted drug delivery is also an important research direction in the improvement of current capsules. According to Woods and Constandinou, future capsules will be equipped with special modules holding a key element: a needle extendible up to $1.5 \mathrm{~mm}$ outside the capsule's body, which would inject the necessary drug in a specific location (68). The needle will be controlled by a single micro-motor, occupying very little space within the capsule.

Enterion is also a drug delivery capsule, with a reservoir of approximately $1 \mathrm{ml}$. It may contain any type of drug that may be released to specific locations of the GI tract, through an opening of $9 \mathrm{~mm}$. The release system is based on a spring and a piston that moves along the shaft of the capsule. The string may be magnetically controlled (69).

In conclusion, almost four decades ago, before WCE, a series of diseases of the small intestine were difficult to 
diagnose. Then, the exploration of the small bowel took a step forward with the development of a new medical procedure that provides a set of images from within the GI tract. Initially, WCE was considered complementary to the existing endoscopic and radiology techniques. But since 2003, it has become the main method for exploring the small bowel.

New WCE prototypes are currently under development, mostly focusing on motion control, tissue sampling and drug administration.

\section{Acknowledgements}

Not applicable.

\section{Funding}

This research was funded by the University of Medicine and Pharmacy of Craiova (grant no. 26/6C, 14/06/2021 and 26/5C, 14/06/2021).

\section{Availability of data and materials}

All information provided in this review is documented by relevant references cited within the manuscript.

\section{Authors' contributions}

AGI, MI and AMC equally contributed to the conception, design of this review, selection of relevant literature findings, and were involved in the drafting of the manuscript. SIZ, ALG and DLP reviewed literature data and structured the tables. ADG, NM and CCV were involved in the critical revisions of the manuscript for important intellectual content in light of the literature findings. All the authors read and approved the final version of the manuscript for publication.

\section{Ethics approval and consent to participate}

Not applicable.

\section{Patient consent for publication}

Not applicable.

\section{Competing interests}

The authors declare that they have no competing interests.

\section{References}

1. Schott GD: Some observations on the history of the use of barium salts in medicine. Med Hist 18: 9-21, 1974.

2. Ilangovan R, Burling D, George A, Gupta A, Marshall M and Taylor SA: CT enterography: Review of technique and practical tips. Br J Radiol 85: 876-886, 2012.

3. Markova I, Kluchova K, Zboril R, Mashlan M and Herman M: Small bowel imaging-still a radiologic approach? Biomed Pap Med Fac Univ Palacky Olomouc Czech Repub 154: 123-132, 2010

4. Iddan GJ and Swain CP: History and development of capsule endoscopy. Gastrointest Endosc Clin N Am 14: 1-9, 2004.
5. Adler SN: The history of time for capsule endoscopy. Ann Transl Med 5: 194, 2017.

6. Eliakim R: The History of Wireless Capsule Endoscopy: From a Dream to a Platform of Capsules. In: Handbook of Capsule Endoscopy. Li Z, Liao Z, McAlindon M (eds). 1st edition. Springer, Dordrecht, 2014.

7. Swain P: Wireless capsule endoscopy. Gut 52 (Suppl 4): iv48-iv50, 2003.

8. Iddan G, Meron G, Glukhovsky A and Swain P: Wireless capsule endoscopy. Nature 405: 417, 2000.

9. Pan G and Wang L: Swallowable wireless capsule endoscopy: Progress and technical challenges. Gastroenterol Res Pract 2012: 841691, 2012

10. Wang Z, Lim E, Tillo T and Yu F: Review of the Wireless Capsule Transmitting and Receiving Antennas. In: Wireless Communications and Networks-Recent Advances. InTech, Shanghai, pp27-46, 2012.

11. Van de Bruaene C, De Looze D and Hindryckx P: Small bowel capsule endoscopy: Where are we after almost 15 years of use? World J Gastrointest Endosc 7: 13-36, 2015.

12. Nakamura T and Terano A: Capsule endoscopy: Past, present, and future. J Gastroenterol 43: 93-99, 2008.

13. Caunedo-Alvarez A, Romero-Vazquez J and Herrerias-Gutierrez JM: Patency and Agile capsules. World J Gastroenterol 14: 5269-5273, 2008.

14. Flemming $\mathbf{J}$ and Cameron S: Small bowel capsule endoscopy. Indications, results, and clinical benefit in a University environment. Medicine (Baltimore) 97: e0148, 2018.

15. Redondo-Cerezo E, Sánchez-Capilla AD, De La Torre-Rubio P and De Teresa J: Wireless capsule endoscopy: Perspectives beyond gastrointestinal bleeding. World J Gastroenterol 20: 15664-15673, 2014.

16. Pennazio M, Spada C, Eliakim R, Keuchel M, May A, Mulder CJ, Rondonotti E, Adler SN, Albert J, Baltes P, et al: Small-bowel capsule endoscopy and device-assisted enteroscopy for diagnosis and treatment of small-bowel disorders: European Society of Gastrointestinal Endoscopy (ESGE) Clinical Guideline. Endoscopy 47: 352-376, 2015.

17. Golli AL, Nitu FM, Balasoiu M, Lungu MA, Dragomirescu CC, Olteanu M, Nemes RM, Tantu MM and Olteanu M: The characterization of antibiotic resistance of bacterial isolates from intensive care unit patient samples in a university affiliated hospital in Romania. Rev Chem 70: 1778-1783, 2019.

18. Golli AL, Nitu FM, Balasoiu M, Lungu MA, Olteanu M, Nemes R, Fortofoiu M and Elena R: Antibiotic resistance pattern of bacterial pathogens in elderly patients admitted in the intensive care unit. Rev Chem 69: 3433-3438, 2018.

19. Olteanu M, Niţu M and Golli A: Tuberculosis mesenteric adenopathy and polyserositis. Rom J Morphol Embryol 53 (Suppl 3): S835-S840, 2012.

20. Zaharie MN, Doina C, Streba CT, Mitrut P, Glodeanu AD, Carstea AP, Zaharie SI, Dascalu IT, Tuculina MJ, Bunget AM, et al: Renal Dysfunction-a Possible e. Rev. Chem 69: 1435-1440, 2018.

21. Carstea D, Streba LA, Glodeanu A, Carstea AP, Vancu M and Ninulescu AM: The accuracy of combined physical examination and ultrasonography for the detection of abdominal aorta aneurysm. Rom J Morphol Embryol 49: 569-572, 2008.

22. Segarajasingam DS, Hanley SC, Barkun AN, Waschke KA, Burtin P, Parent J, Mayrand S, Fallone CA, Jobin G, Seidman EG and Martel M: Randomized controlled trial comparing outcomes of video capsule endoscopy with push enteroscopy in obscure gastrointestinal bleeding. Can J Gastroenterol Hepatol 29: 85-90, 2015.

23. Triester SL, Leighton JA, Leontiadis GI, Fleischer DE, Hara AK, Heigh RI, Shiff AD and Sharma VK: A meta-analysis of the yield of capsule endoscopy compared to other diagnostic modalities in patients with obscure gastrointestinal bleeding. Am J Gastroenterol 100: 2407-2418, 2005.

24. Ell C, Remke S, May A, Helou L, Henrich R and Mayer G: The first prospective controlled trial comparing wireless capsule endoscopy with push enteroscopy in chronic gastrointestinal bleeding. Endoscopy 34: 685-689, 2002.

25. Lewis BS and Swain P: Capsule endoscopy in the evaluation of patients with suspected small intestinal bleeding: Results of a pilot study. Gastrointest Endosc 56: 349-353, 2002.

26. Mylonaki M, Fritscher-Ravens A and Swain P: Wireless capsule endoscopy: A comparison with push enteroscopy in patients with gastroscopy and colonoscopy negative gastrointestinal bleeding. Gut 52: 1122-1126, 2003. 
27. Laine L, Sahota A and Shah A: Does capsule endoscopy improve outcomes in obscure gastrointestinal bleeding? Randomized trial versus dedicated small bowel radiography. Gastroenterology 138 : 1673-1680. e1; quiz e11-2, 2010.

28. Van Weyenberg SJ, Smits F, Jacobs MA, Van Turenhout ST and Mulder CJ: Video capsule endoscopy in patients with nonresponsive celiac disease. J Clin Gastroenterol 47: 393-399, 2013.

29. Khalife S, Soyer P, Alatawi A, Vahedi K, Hamzi L, Dray X, Placé V, Marteau P and Boudiaf M: Obscure gastrointestinal bleeding: Preliminary comparison of 64-section CT enteroclysis with video capsule endoscopy. Eur Radiol 21: 79-86, 2011.

30. Leung WK, Ho SS, Suen BY, Lai LH, Yu S, Ng EK, Ng SS, Chiu PW, Sung JJ, Chan FK and Lau JY: Capsule endoscopy or angiography in patients with acute overt obscure gastrointestinal bleeding: A prospective randomized study with long-term follow-up. Am J Gastroenterol 107: 1370-1376, 2012.

31. Choi M, Lim S, Choi MG, Shim KN and Lee SH: Effectiveness of capsule endoscopy compared with other diagnostic modalities in patients with small bowel crohn's disease: A meta-analysis. Gut Liver 15: 62-72, 2017.

32. Albert JG, Martiny F, Krummenerl A, Stock K, Lesske J, Göbel CM, Lotterer E, Nietsch HH, Behrmann C and Fleig WE: Diagnosis of small bowel Crohn's disease: A prospective comparison of capsule endoscopy with magnetic resonance imaging and fluoroscopic enteroclysis. Gut 54 1721-1727, 2005.

33. Crook DW, Knuesel PR, Froehlich JM, Eigenmann F, Unterweger M, Beer HJ and Kubik-Huch RA: Comparison of magnetic resonance enterography and video capsule endoscopy in evaluating small bowel disease. Eur J Gastroenterol Hepatol 21: 54-65, 2009.

34. Jensen MD, Nathan T, Rafaelsen SR and Kjeldsen J: Diagnostic accuracy of capsule endoscopy for small bowel Crohn's disease is superior to that of MR enterography or CT enterography. Clin Gastroenterol Hepatol 9: 124-129, 2011.

35. Triester SL, Leighton JA, Leontiadis GI, Gurudu SR, Fleischer DE, Hara AK, Heigh RI, Shiff AD and Sharma VK: A meta-analysis of the yield of capsule endoscopy compared to other diagnostic modalities in patients with non-stricturing small bowel Crohn's disease. Am J Gastroenterol 101: 954-964, 2006.

36. Dubcenco E, Jeejeebhoy KN, Petroniene R, Tang SJ, Zalev AH, Gardiner GW and Baker JP: Capsule endoscopy findings in patients with established and suspected small-bowel Crohn's disease: Correlation with radiologic, endoscopic, and histologic findings. Gastrointest Endosc 62: 538-544, 2005.

37. Voderholzer WA, Beinhoelzl J, Rogalla P, Murrer S, Schachschal G, Lochs H and Ortner MA: Small bowel involvement in Crohn's disease: A prospective comparison of wireless capsule endoscopy and computed tomography enteroclysis. Gut 54: 369-373, 2005.

38. Eliakim R: Wireless capsule video endoscopy: Three years of experience. World J Gastroenterol 10: 1238-1239, 2004

39. Hara AK, Leighton JA, Heigh RI, Sharma VK, Silva AC, De Petris G, Hentz JG and Fleischer DE: Crohn disease of the small bowel: Preliminary comparison among CT enterography, capsule endoscopy, small-bowel follow-through, and ileoscopy. Radiology 238: 128-134, 2006

40. Solem CA, Loftus EV Jr, Fletcher JG, Baron TH, Gostout CJ, Petersen BT, Tremaine WJ, Egan LJ, Faubion WA, Schroeder KW, et al: Small-bowel imaging in Crohn's disease: A prospective, blinded, 4-way comparison trial. Gastrointest Endosc 68: 255-266, 2008

41. Bourreille A, Jarry M, D'Halluin PN, Ben-Soussan E, Maunoury V, Bulois P, Sacher-Huvelin S, Vahedy K, Lerebours E, Heresbach D, et al: Wireless capsule endoscopy versus ileocolonoscopy for the diagnosis of postoperative recurrence of Crohn's disease: A prospective study. Gut 55: 978-983, 2006

42. Pons Beltrán V, Nos P, Bastida G, Beltrán B, Argüello L, Aguas M, Rubín A, Pertejo V and Sala T: Evaluation of postsurgical recurrence in Crohn's disease: A new indication for capsule endoscopy? Gastrointest Endosc 66: 533-540, 2007.

43. Leighton JA, Srivathsan K, Carey EJ, Sharma VK, Heigh RI, Post JK, Erickson PJ, Robinson SR, Bazzell JL and Fleischer DE: Safety of wireless capsule endoscopy in patients with implantable cardiac defibrillators. Am J Gastroenterol 100: 1728-1731, 2005.

44. Akin E and Ersoy O: Capsule endoscopy in celiac disease. Gastroenterol Res Pract 2012: 676073, 2012.
45. Costamagna G, Shah SK, Riccioni ME, Foschia F, Mutignani M, Perri V, Vecchioli A, Brizi MG, Picciocchi A and Marano P: A prospective trial comparing small bowel radiographs and video capsule endoscopy for suspected small bowel disease. Gastroenterology 123: 999-1005, 2002.

46. Bailey AA, Debinski HS, Appleyard MN, Remedios ML, Hooper JE, Walsh AJ and Selby WS: Diagnosis and outcome of small bowel tumors found by capsule endoscopy: A three-center Australian experience. Am J Gastroenterol 101: 2237-2243, 2006.

47. Mata A, Llach J and Bordas JM: Wireless capsule endoscopy. World J Gastroenterol 14: 1969-1971, 2008.

48. Singeap AM, Stanciu C and Trifan A: Capsule endoscopy: The road ahead. World J Gastroenterol 22: 369-378, 2016.

49. Saurin JC, Delvaux M, Vahedi K, Gaudin JL, Villarejo J, Florent C, Gay G and Ponchon T: Clinical impact of capsule endoscopy compared to push enteroscopy: 1-year follow-up study. Endoscopy 37: 318-323, 2005.

50. Ross A, Mehdizadeh S, Tokar J, Leighton JA, Kamal A, Chen A, Schembre D, Chen G, Binmoeller K, Kozarek R, et al: Double balloon enteroscopy detects small bowel mass lesions missed by capsule endoscopy. Dig Dis Sci 53: 2140-2143, 2008.

51. Haanstra JF, Al-Toma A, Dekker E, Vanhoutvin SA, Nagengast FM, Mathus-Vliegen EM, van Leerdam ME, de Vos tot Nederveen Cappel WH, Sanduleanu S, Veenendaal RA, et al: Prevalence of small-bowel neoplasia in Lynch syndrome assessed by video capsule endoscopy. Gut 64: $1578-1583,2015$

52. Caspari R, von Falkenhausen M, Krautmacher C, Schild H, Heller J and Sauerbruch T: Comparison of capsule endoscopy and magnetic resonance imaging for the detection of polyps of the small intestine in patients with familial adenomatous polyposis or with Peutz-Jeghers' syndrome. Endoscopy 36: 1054-1059, 2004.

53. Brown G, Fraser C, Schofield G, Taylor S, Bartram C, Phillips R and Saunders B: Video capsule endoscopy in peutz-jeghers syndrome: A blinded comparison with barium follow-through for detection of small-bowel polyps. Endoscopy 38: 385-390, 2006.

54. Thomson M, Fritscher-Ravens A, Mylonaki M, Swain P, Eltumi M, Heuschkel R, Murch S, McAlindon M and Furman M: Wireless capsule endoscopy in children: A study to assess diagnostic yield in small bowel disease in paediatric patients. J Pediatr Gastroenterol Nutr 44: 192-197, 2007.

55. Gupta R, Lakhtakia S, Tandan M, Banerjee R, Ramchandani M, Anuradha S, Ramji C, Rao GV, Pradeep R and Reddy DN: Capsule endoscopy in obscure gastrointestinal bleeding-an Indian experience. Indian J Gastroenterol 25: 188-190, 2006.

56. Streba CT, Ionescu M, Vere CC and Rogoveanu I: Artificial Intelligence and Automatic Image Interpretation in Modern Medicine. In: Translational Bioinformatics and Its Application. Translational Medicine Research. Wei DQ, Ma Y, Cho W, Xu Q, Zhou F (eds.). Springer, Dordrecht, 2017.

57. Soffer S, Klang E, Shimon O, Nachmias N, Eliakim R, Ben-Horin S, Kopylov U and Barash Y: Deep learning for wireless capsule endoscopy: A systematic review and meta-analysis. Gastrointestinal Endoscopy 92: 831-839.e8, 2020.

58. Hwang Y, Park J, Lim YJ and Chun HJ: Application of artificial intelligence in capsule endoscopy: Where are we now? Clin Endosc 51: 547-551, 2018.

59. Constantinescu AF, Ionescu M, Iovanescu VF, Ciurea ME, Ionescu AG, Streba CT, Bunescu MG, Rogoveanu I and Vere CC: A computer-aided diagnostic system for intestinal polyps identified by wireless capsule endoscopy. Rom J Morphol Embryol 57: 979-984, 2016

60. Ionescu M, Vatamanu OA, Apostol S, Frandes M, Mihalas GI, Ciurea ME and Vere CC: Comparative study of contour detection methods for intestinal sessile polyps. E-Health and Bioengineering Conference (EHB): 1-4, 2013

61. Trasolini R and Byrne MF: Artificial intelligence and deep learning for small bowel capsule endoscopy. Dig Endosc 33: 290-297, 2021.

62. Dray X, Iakovidis D, Houdeville C, Jover R, Diamantis D, Histace A and Koulaouzidis A: Artificial intelligence in small bowel capsule endoscopy-current status, challenges and future promise. J Gastroenterol Hepatol 36: 12-19, 2021.

63. Koulaouzidis A, Iakovidis DK, Karargyris A and Rondonotti E: Wireless endoscopy in 2020: Will it still be a capsule? World J Gastroenterol 21: 5119-5130, 2015 
64. Koprowski R: Overview of technical solutions and assessment of clinical usefulness of capsule endoscopy. Biomed Eng Online 14: $111,2015$.

65. Ciuti G, Calio R, Camboni D, Neri L, Bianchi F, Arezzo A Koulaouzidis A, Schostek S, Stoyanov D, Oddo CM, et al: Frontiers of robotic endoscopic capsules: A review. J Microbio Robot 11: 1-18, 2016.

66. Kwack WG and Lim YJ: Current status and research into overcoming limitations of capsule endoscopy. Clin Endosc 49: 8-15, 2016.

67. Yim S, Gultepe E, Gracias DH and Sitti M: Biopsy using a magnetic capsule endoscope carrying, releasing, and retrieving untethered microgrippers. IEEE Trans Biomed Eng 61: 513-521, 2014.
68. Woods SP and Constandinou TG: Wireless capsule endoscope for targeted drug delivery: Mechanics and design considerations. IEEE Trans Biomed Eng 60: 945-953, 2013.

69. Woods SP and Constandinou TG: A compact targeted drug delivery mechanism for a next generation wireless capsule endoscope. J Micro-Bio Robot 11: 19-34, 2016.

(c) (7) This work is licensed under a Creative Commons

EY NG NO Attribution-NonCommercial-NoDerivatives 4.0 International (CC BY-NC-ND 4.0) License. 